\title{
Analisis Fasilitas Pejalan Kaki dan Aksesibilitas Halte dan Stasiun Kereta Commuter Surabaya Porong
}

\author{
Ahmad Soimun ${ }^{1 *}$ Email : Soimun@poltradabali.ac.id \\ Arinda Leliana²Email : arinda@ppi.ac.id \\ Manajemen Logistik ${ }^{1}$, Politeknik Transportasi Darat Bali, Indonesia ${ }^{1}$ \\ Manajemen Transportasi Perkeretaapian ${ }^{2}$,Politeknik Perkeretaapian Indonesia Madiun ${ }^{2}$
}

\begin{abstract}
ABSTRAK
Kota surabaya menjadi pusat kegiatan seperti perdagangan, industri bisnis dan pusat pemerintahan sehingga menuntut untuk orang melakukan kunjungan kekota tersebut. Untuk menarik minat masyarakat hinterland nya diperlukan angkutan umum yang dapat menjadi andalan dan memperhatikan jadwal layanan, ketepatan waktu dan headway. Sehingga angkutan umum tersebut dapat mengurangi tingkat kemacetan di kota tujuan dalam hal ini kota Surabaya. Perlu difikirkan juga konektifitas, fasilitas dan aksesbilitas di stasiun halte sebagai tempat baik turunnya penumpang. Kereta api commuter Surabaya Porong harus terkoneksi dengan angkutan lainya sehingga perlu diperhatikan fasilitas dan aksesibilitas disetiap halte dan stasiun pemberhentian. Pengumpulan data dan survey dilakukan secara observasi langsung dilapangan dengan survey, mangamati dan mengukur fasilitas dan aksesbilitas yang ada. Fasilitas dan askesibilitas dari halte dan stasiun kereta commuter Surabaya Porong terlihat sudah ada sebagian meskipun ada kekurangan tetapi masih bisa berjalan untuk operasional masyarakat sekitar Surabaya dan Sidoarjo. Berdasarkan hasil analisis laju arus pejalan kaki pada waktu penelitian menunjukan nilai LOS untuk halte dan stasiun masih sangat baik dengan kategori A-B.
\end{abstract}

Kata Kunci: Fasilitas,Aksesibilitas,LOS,StasiunKereta,Commuter

\section{ABSTRACT}

The city of Surabaya is the center of activities such as trade, business industry, and the center of government, so it demands people to visit the city. To attract the interest of the hinterland community, public transportation is needed that can be a mainstay and pay attention to service schedules, punctuality, and headway. So that public transportation can reduce the level of congestion in the destination city, in this case, the city of Surabaya. It is also necessary to think about connectivity, facilities, and accessibility at the bus stop station as a good place for passengers to drop off. The Surabaya Porong commuter train must be connected to other transportation so that it is necessary to pay attention to facilities and accessibility at every bus stop and station. Data collection and surveys are carried out by direct observation in the field with surveys, observing and measuring existing facilities and accessibility. The facilities and accessibility of the Surabaya Porong bus stop and commuter train station appear to have been partially available, although there are shortcomings, they can still run for the operations of the communities around Surabaya and Sidoarjo. Based on the results of the analysis of the pedestrian flow rate at the time of the study, the LOS values for bus stops and stations were still very good with the AB category.

Keywords: Facilities, Accessibility, LOS, Train Station, Commuter

\section{INFORMASI UMUM}

Kota surabaya merupakan pusat kota di Jawa Timur yang berkembang pesat dan menjadi kota terbesar kedua setelah kota Jakarta. Sama seperti hal di kota jakarta yang disanggah oleh kota hinterland Jabodetabek. Kota surabaya juga di sanggah oleh beberapa kabupaten disekitarnya yang salah satunya adalah Kabupaten Sidoarjo. Kota surabaya menjadi pusat kegiatan seperti kegiatan perdagangan, industri bisnis dan pusat pemerintahan sehingga menuntut untuk orang melakukan kunjungan kekota tersebut.
Aktifitas warga hinterland kota surabaya yang melakukan kegiatan commuter sangat membutuhkan moda transportasi yang bisa melayani dengan baik. Moda transportasi tersebut bisa diandalkan untuk mobilitas baik waktu berangkat waktu pulang kerumah masing masing.

Pergerakan perjalanan memasuki pusat kota Surabaya cenderung tinggi dari tujuan daerah hinterland. Jumlah penduduk kota surabaya menurut Badan Pusat Statistik tahun 2016 tercatat sekitar 2.853.661 jiwa. Pada siang 
hari jumlah penduduk yang beraktifitas di kota Surabaya mencapai 5-6 juta jiwa. Pergerakan perjalanan ke pusat kota surabaya didominasi perjalanan yang sifatnya rutin seperti bekerja, bisnis, perdagangan. Kabupaten Sidoarjo merupakan daerah hinterland terdekat dari kota Surabaya sehingga aktifitas perjalanan masyarakatnya berpengaruh terhadap aktifitas perjalanan ke kota Surabaya.

Operasional kereta commuter Surabaya Porong memiliki jadwal keberangkatan semula 5 kali perjalanan. Menurut jadwal yang di rilis pada bulan oktober tahun 2017 jadwal pemberangkatan kereta commuter Surabaya Porong menjadi 3 kali keberangkatan dimulai dari stasiun porong. Kebijakan ini diberlakukan oleh PT. KAI untuk efisiensi operasional kereta commuter (PT KAI, 2016).

Untuk menarik minat masyarakat hinterland nya diperlukan kereta api yang dapat menjadi andalan dan memperhatikan layanan jadwal, headway dan ketepatan waktu kereta. Sehingga kereta api tersebut dapat mengurangi tingkat kemacetan di kota tujuan dalam hal ini kota Surabaya. Perlu difikirkan juga konektifitas, fasilitas dan aksesbilitas di stasiun halte sebagai tempat baik turunnya penumpang. Kereta commuter Surabaya Porong untuk meningkatkan minat pengguna harus terkoneksi dengan angkutan lainya sehingga perlu diperhatikan fasilitas dan aksesibilitas disetiap halte dan stasiun pemberhentian. Faktor-faktor juga perlu diperhatikan untuk mencari solusi terbaik dalam mengatasi permasalahanpermasalahan kurangnya minat masyarakat untuk menggunakan kereta tersebut. Sehingga penangganan yang baik menghasilkan angkutan kereta commuter yang menjadi andalan bagi masyarakat untuk melakukan kegiatan aktifitas dan juga menghasilkan kinerja kereta commuter yang lebih baik.

Setiap orang yang melakukan kegiatan perjalanan membutuhkan fasilitas yang terhubung dengan baik dari keberangkatan menuju tujuannya. Berkaitan dengan hal ini konektifitas dan tingkat aksesibilitas sangat dibutuhkan. Konektifitas dapat dikatakan keterhubungan antar beberapa titik yang dihubungkan oleh sistem jaringan jalan. Suatu lokasi dapat dinilai memiliki konektifitas apabila memiliki keterhubungan dengan lokasi lainya.

Aksesibilitas yang inginkan merupakan adanya sarana dan prasarana yang mendukung untuk dapat mempermudah kelancaran dalam menjangkau antar lokasi setempat. Tingkat aksesibilitas suatu kota dapat dilihat dengan ketersediaan angkutan umum perkotaan yang melayani perkotaan tersebut (Tamin, 2000).

Variabel yang mempengaruhi tingkat aksesibilitas yaitu tinggi rendahnya sistem jaringan penghubung yang ada pada daerah tersebut. Semakin banyak sistem jaringan akan memudahkan aksesibilitas, begitu juga dengan semakin rendah sistem jaringan akan menyulitkan daerah tersebut dijangkau oleh pergerakan orang. Kelancaan pelayanan umum dapat di pengaruhi oleh jaringan transportasi karena sangat penting bagi kelancaran aktifitas pergerakan masyarakat.

Aksesibilitas dari pengguna kereta commuter Surabaya Porong diharapkan mampu untuk menarik minat masyarakat yang bepergian menggunakan moda lain seperti kendaraan pribadi yang menambah tingkat kemacetan kota. Dalam hal ini fasilitas dan aksesibilitas yang ada harus di identifikasi tingkat kesesuaian dan tingkat pelayanan yang diberikan. Faslitas dan aksesibilitas dapat tinjau dari kelengkapan sarana dan prasana pedestrian. Jalur pedestrian bisa meningkatkan keamanan dan kenyamanan pada penggunanya (Sudiarta, 2016) (Harsono, 2016).

\section{TINJAUAN PUSTAKA}

Pedestrian merupakan fasilitas seluruh bangunan pelengkap yang disediakan untuk pejalan kaki yang berguna memberikan pelayanan untuk kelancaran, keamanan, kenyamanan dan keselamatan (Dirjen Bina Marga, 1999). Perencanaan prasarana dan sarana pedestrian dapat diuraikan dari karakteristik pedestrian dasar dan penerapannya dalam pendesainan fasilitas fasilitas pedestrian. Konsep tingkat - pelayanan yang berhasil digunakan dalam desain jalan raya, diterapkan pula dalam desain pedestrian dan fasilitas penunjangnya. Keberadaan pejalan kaki sebagai salah satu dari pengguna transportasi perlu diperhatikan fasilitas yang baik dan terencana. Berikut merupakan asilitas pejalan kaki yang dibedakan menjadi dua jenis yaitu :

\section{a. Fasilitas Prasarana Pedestrian}

a. Penyeberangan Sebidang (At-Grade) :

- Penyeberangan Zebra dan PElikan

- Trotoar pejalan kaki

b. Penyeberangan Tidak Sebidang (Elevated/Underground)

- Elevated/Jembatan

- Underground/Terowongan

\section{b. Fasilitas Sarana Ruang Pejalan Kaki}

sistem jalur pejalan kaki dari tepi jalan raya hingga tepi terluar lahan milik bangunan merupakan fasilitas dari ruang pejalan kaki disisi jalan (sidewalk), (Anggraini, 2009)

Keputusan menteri perhubungan tentang fasilitas pendukung kegiatan lalu lintas dan angkutan jalan KM 65 tahun 1993 mengatur tentang persayaran teknis penyediaan sarana ruang pejalan kaki. Fasilitas yang dimaksud dalam sarana ruang pejalan kaki sebagai berikut :

a. Drainase

Drainase merupakan penampung dan saluran air pada ruang pejalan kaki. Letak dari drainase ini biasanya berdampingan atau dibawah dari ruang pejalan kaki. Adanya drainase disini berfungsi untuk mencegah 
terjadinya banjir dan genangan air yang berlebih saat musim hujan. Drainase memiliki dimensi lebar $50 \mathrm{~cm}$ dan tinggi $50 \mathrm{~cm}$ ukuran ini tergantung dari debit air saluran sekitarnya.

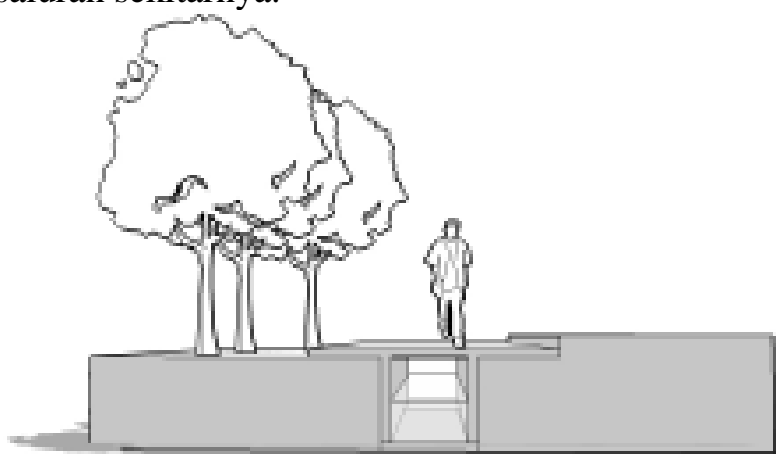

Gambar 1 Drainase

(Sumber: Pedoman penyediaan prasarana sarana ruang pejalan kaki di perkotaan)

\section{b. Jalur Hijau}

Jalur hijau berfungsi untuk peneduh pejalan kaki sehigga harus diperhatikan jenis tanaman untuk jalur hijau terebut. Letak dari jalur hijau berada pada jalur amenitas dengan jalur $150 \mathrm{~cm}$.

\section{c. Lampu Penerangan}

Fungsi dari lampu penerangan untuk memberikan cahaya pada malam hari dan memberikan ketenangan kepada orang yang melintas. Letak dari lampu penerangan berada pada jalur amenitas dan berjarak setiap $10 \mathrm{~m}$ dengan tinggi maksimal $4 \mathrm{~m}$. material dipakai merupakan bahan dengan durabilitas yang tinggi seperti metal dan beton pracetak.

d. Tempat Duduk

Fungsi dari tempat duduk untuk tempat istirahat pejalan kaki sehingga perletakan dari tempat duduk berada pada jalur amenitas. Lokasi dari tempat duduk setiap $10 \mathrm{~m}$, dengan lebar sekitar $40-50 \mathrm{~cm}$ dan panjang $150 \mathrm{~cm}$. bahan yang digunakan haruslah bahan dengan durabilitas yang tinggi seperti metal dan beton cetak.

e. Pagar Pengaman

Fungsi dari pagar pengaman memberikan pengamanan pada pejalan kaki dari arus lalu lintas jalan. Perletakan berada pada jalur amenitas sehingga diperlukan tinggi sekitar $90 \mathrm{~cm}$, bahan yang bisa dipakai seperti metal, beton atau material yang tahan terhadap cuaca, kerusakan dan mudah pemeliharaannya.

f. Tempat Sampah

Tempat sampah diperlukan untuk memperindah pemandangan agar pejalan kaki tidak membuang sampah sembarang tempat. Perlelatakan dari tempat sampah berada pada jalur amenitas diletakan setaip 20 $m$ dengan pemisahan sesuai jenis sampah.

g. Marka, Perambuan, Papan Informasi (Signage)

Fungsi dari Marka dan perambuan, papan informasi

(signage) sebagai penanda adanya fasilitas pejalan kaki kepada pengendara lalu lintas yang padat. Perletakannya berada pada jalur amenitas pada titik interaksi sosial. Bahan yang digunakan memiliki durabilitas yang tinggi dan tidak menimbulkan efek silau.

h. Halte/Shelter Bus dan Lapak Tunggu

Halte/shelter merupakan tempat berhenti angkutan umum yang berfungsi untuk menaik turunkan penumpang. Perletakan dari halte harus diperhatikan yang merupakan titik potensial kawasan.

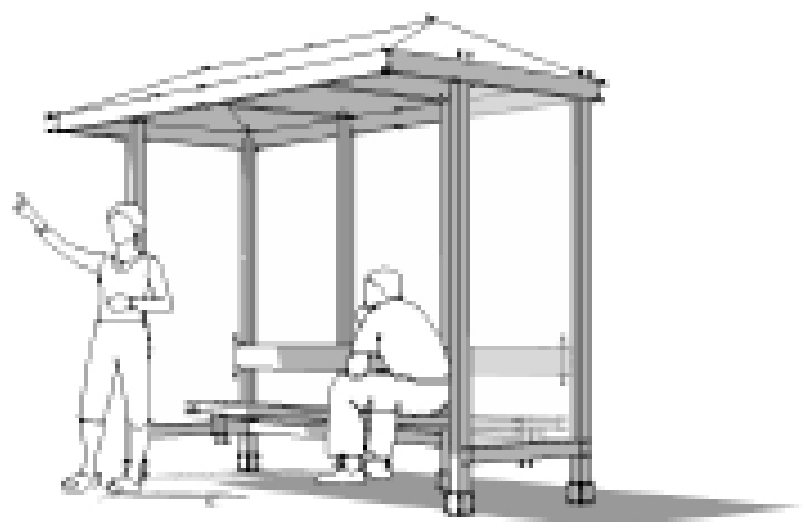

Gambar 2 Fasilitas Halte/Shelter Bus dan Lapak Tunggu

(Sumber: Pedoman penyediaan prasarana sarana ruang pejalan kaki di perkotaan)

\section{c. Karakteristik Pejalan Kaki}

Pergerakan seseorang dalam kondisi berdiri tegak membutuhkan minimum ruang sehingga perlu kebutuhan ruang tertentu atau body elipse. Kebutuhan ruang dimensi kurang lebih 18 in x 24 in. Syarat ruang minimum dengan luas $2,30 \mathrm{~m}^{2} /$ ped ini tidak cukup jika seseorang membawa barang-barang atau tas punggung. Untuk kenyamanan seseorang dianjurkan dengan luas 7 hingga $10 \mathrm{~m}^{2} /$ ped. Seperti yang ditampilkan pada gambar dibawah ini.

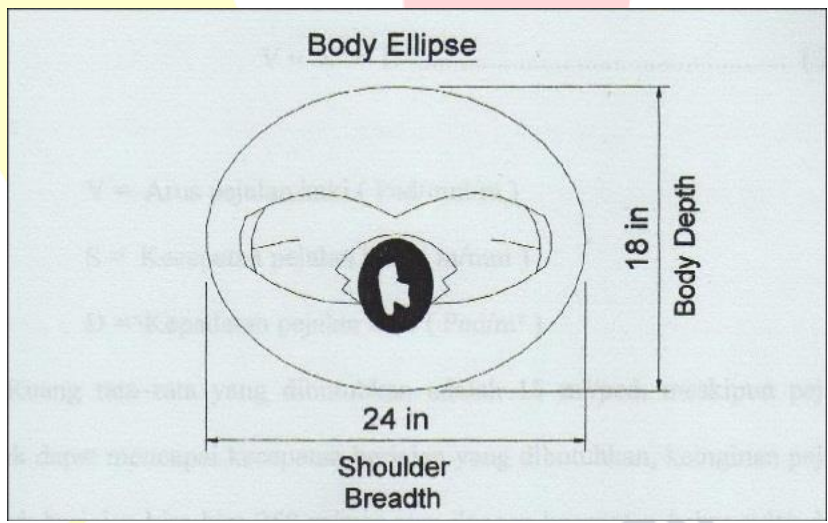

Gambar 3 Ruang Minimum Seseorang Ketika Berdiri Tegak (Body Elip)

(Sumber: Khisty, 2003)

Karakteristik pejalan kaki merupakan faktor penting dalam perencanaan dan pengoperasian sistem transportasi. Aktifitas pejalan kaki dapat dirasakan dari 
karakteristik pejalan kaki yang disediakan atau pelayanan yang diberikan. Prinsip - prinsip analisis pergerakan pejalan kaki berdasarkan pada lebar efektif pedestrian dapat dilihat pada gambar 2.5

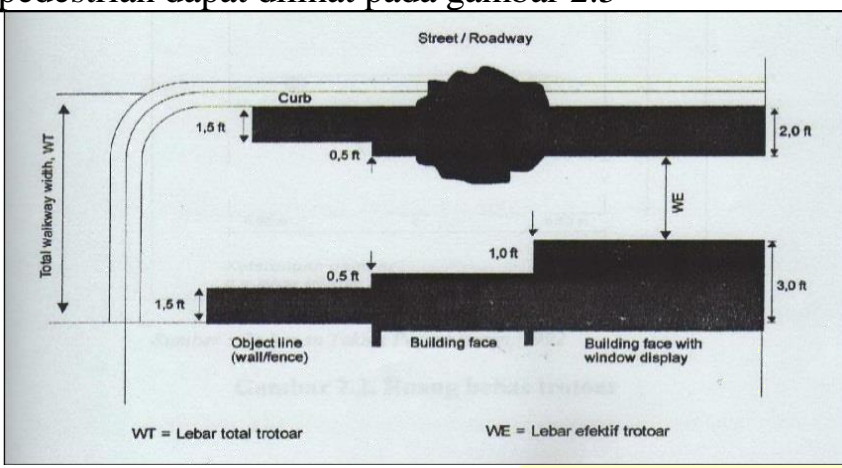

Gambar 4 Lebar Efektif Pejalan Kaki

(Sumber: Khisty, 2003)

\section{d. Tingkat Pelayanan Pejalan Kaki (Level Of Servis)}

Dalam mendesain fasilitas pedestrian perlu diperhatikan Fakstor-faktor yang harus dipertimbangkan diantaranya :

Tabel 1 Tingkat Pelayanan Pejalan Kaki Level Of Servis

\begin{tabular}{|c|c|c|c|c|}
\hline \multicolumn{5}{|c|}{ Kriteria LOS Arus Rata - rata untuk Jalan Orang dan Trotoar } \\
\hline \multirow{2}{*}{$\begin{array}{c}\text { Tingkat } \\
\text { Pelayanan }\end{array}$} & Ruang & Laju Arus & Kecepatan & Rasio \\
\cline { 2 - 5 } & $\mathrm{FT}^{2} /$ orang & orang/menit/ft & $\mathrm{ft} /$ detik & $\mathrm{v} / \mathrm{c}$ \\
\hline $\mathrm{A}$ & $>60$ & $\leq 5$ & $>4.5$ & $\leq 0.21$ \\
\hline $\mathrm{B}$ & $>40-60$ & $>5-7$ & $>4.17-4.25$ & $>0.21-0.31$ \\
\hline $\mathrm{C}$ & $>24-40$ & $>7-10$ & $>4.00-4.17$ & $>0.31-0.44$ \\
\hline $\mathrm{D}$ & $>15-24$ & $>10-15$ & $>3.75-4.00$ & $>0.44-0.65$ \\
\hline $\mathrm{R}$ & $>8-15$ & $>15-23$ & $>2.50-3.75$ & $>0.65-1.0$ \\
\hline $\mathrm{F}$ & $\leq 8$ & Beragam & $\leq 2.50$ & Beragam \\
\hline \multicolumn{5}{|c}{ Keadaan rata - rata selama 15 menit } \\
\hline \multicolumn{5}{|c}{} \\
\hline
\end{tabular}

Menurut khisty 2003 tingkat pelayanan perjalan kaki terbagi menjadi 6 bagian Highway Capacity Manual (HCM) 2000 yang masing masing terdapat kriteria yang berbeda seperti :

1. Level of Service A (LOS A)

Kecepatan berjalan bebas dan kemungkinan terjadinya konflik diantara pedestrian sangat kecil.

2. Level of Service B (LOS B)

Pengguna pedestrian mulai menyadari akan adanya orang lain dan menanggapi kehadiran mereka itu ketika memilih lintasan berjalannya.

3. Level of Service C (LOS C)

Gerak arah-balik atau silang dapat menyebabkan sedikit konflik dan kecepatan serta laju alirnya agak lebih rendah.

4. Level of Service D(LOS D)
LOS ini memberikan arus yang cukup lancar, tetapi gesekan dan interaksi di antara pedestrian itu kemungkinan terjadi.

5. Level of Service E (LOS E)

Volume desain mendekati batas kapasitas jalan orang dengan berhenti atau arus yang terhambat.

6. Level of Service F (LOS F)

Ruangnya lebih mengkarakter kan pedestrian yang antri daripada arus pedestrian yang bergerak

\section{METODE PENELITIAN}

Observasi lapangan Survey pedestrian dilakukan di beberapa titik halte/shelter dengan cara melakukan observasi kondisi halte, wawancara kepada petugas halte serta menghitung dimensi dari masing-masing halte. Jenis pengamatan adalah deskriptif sedangkan pengambilan data dilakukan berdasarkan kondisi dilapangan, data yang diambil meliputi :

a. Jumlah penumpang yang berada pada peron dan halte

b. Geometri peron dan halte

Observasi lapangan dilakukan pada kurun waktu 23-28 oktober 2017. Waktu pengamatan dilakukan pada siang hari (13.15 WIB - 14.34 WIB pada hari senin 23 Oktober 2017 rute Surabaya - Porong) dan sore hari (15.50 WIB - 17.20 WIB pada hari senin 23 Oktober 2017 rute Porong - Surabaya).

Pengamatan dilakukan dengan keterbatasan waktu, tenaga, dan biaya. Data yang diperoleh dari hasil pengamatan di lapangan kemudian digunakan sebagai bahan masukan dalam perhitungan untuk menentukan tingkat pelayanan (level of service).

\section{PEMBAHASAN}

\section{A. Aksesibilitas dari Responden Penumpang Kereta Commuter Surabaya Porong}

Menurut responden moda untuk menggunakan kereta commuter harus ada perpindahan moda dikarenakan lokasi stasiun/halte yang tidak berada di daerah tempat tinggal responden. Sehingga perlu dianalisis moda yang digunakan oleh responden sebelum naik kereta commuter dan sesudah menggunakan kereta commuter. Dan juga perlu diperhatikan fasilitas tempat parkir kendaraan dilokasi halte/stasiun dan koneksi dengan moda lain setelah menggunakan kereta commuter.

\section{Moda Transportasi ke Halte/Stasiun}

Menurut reponden moda transportasi yang digunakan untuk ke stasiun/halte rata rata responden menjawab menggunakan sepeda motor $55 \%$, jalan kaki $21 \%$, angkutan umum $16 \%$, antar jemput $4 \%$, mobil pribadi $3 \%$, dan taksi $1 \%$. Distribusi penggunaan moda menuju halte/stasiun dapat dilihat pada gambar 9 


\section{Moda Transportasi ke Halte/Stasiun}

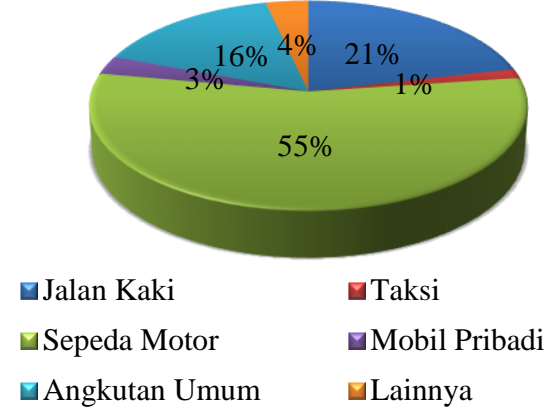

Gambar 5 Moda transportasi ke halte/stasiun Sumber : (Soimun, 2018)

Menurut hasil survey dari gambar 9 pengguna sebelum menggunakan kereta api responden menjawab menggunakan sepeda motor. Hal ini dapat di simpulkan bahwa pengelola halte/stasiun diharapkan menyedakan lokasi parkir yang cukup luas untuk parkir kendaraan.

\section{Moda Transportasi Meninggalkan Halte/Stasiun} Dari hasil survey didapatkan moda transportasi untuk meninggalkan halte/stasiun ke tujuan akhir adalah sepeda motor sebesar $46 \%$, jalan kaki sebesar $26 \%$, angkutan umum sebesar 23\%, antar jemput sebesar 3\%, untuk pengguna mobil pribadi dan taksi sebesar $1 \%$. Distribusi moda yang digunakan untuk meninggalkan halte/stasiun dapat dilihat pada gambar 10

\section{Moda Transportasi Meninggalkan} Halte/Stasiun

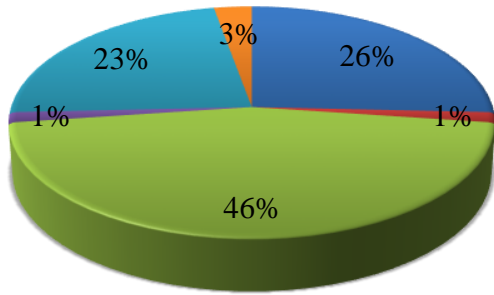

$$
\begin{array}{ll}
\square \text { Jalan Kaki } & \square \text { Taksi } \square \text { Sepeda Motor } \\
\square \text { Mobil Pribadi } & \square \text { Angkutan Umum } \square \text { Lainnya }
\end{array}
$$

Gambar 6 Moda transportasi meninggalkan halte/stasiun

Sumber : (Soimun, 2018)

Dari hasil survey responden dan observasi lapangan, responden lebih banyak menggunakan sepeda motor untuk moda lanjutan setelah menggunakan kereta commuter. Selanjutnya jawaban responden dengan berjalan kaki juga mendapatkan angka prosentase yang cukup besar. Sama dengan pernyataan sebelumnya dimana lokasi parkir untuk kendaraan sepeda motor sangat dibutuhkan dan juga dilihat dari jumlah berjalan kaki juga cukup besar sehingga bisa di simpulkan bahwa pengguna kereta commuter memiliki tempat tinggal yang tidak jauh dari lokasi halte/stasiun.

\section{B. Fasilitas dan Aksesbilitas Halte Stasiun \\ 1. Halte ngagel}

Letak dari halte ngagel berada dikelurahan Kertajaya, kecamatan Gubeng Surabaya.

Menurut papan informasi halte ini berada pada ketinggian +7 mdpl letak halte ini berada pada jarak 2.6 $\mathrm{km}$ selatan stastiun Wonokromo. Halte ini memiliki dua jalur kereta dan terdapat bangunan di kedua sisi jalur yang di antaranya dihubungkan sebuah terowongan penghubung. Hanya KA Komuter yang berhenti di halte ini.

\section{$>$ Aksesbilitas :}

Halte ngagel memiliki aksesbilitas yang sukar untuk dijangkau, karena posisinya yang berada jauh dari jalan mayor. Halte ini terletak di lingkungan yang sarat dengan pemukiman penduduk. Tidak tersedia angkutan umum pada lingkungan Halte Ngagel. Kondisi internmoda yang kurang pada Halte Ngagel mempersulit para pengguna komuter yang ingin menuju lokasi lain.

$>$ Fasilitas pada Halte Ngagel

Dimensi dari halte ini sekitar $3 \mathrm{~m} \mathrm{x} 100 \mathrm{~m}$ dengan fasilitas ruang penjualan tiket. Halte ini dihubungkan oleh terowongan penghubung sebagai jalur penyebrangan yang melintasi double track diatasmya. Kondisi terowongan penghubung sudah tidak dapat digunakan lagi karena dibanjiri oleh air dengan tinggi $\pm 50-100 \mathrm{~cm}$.

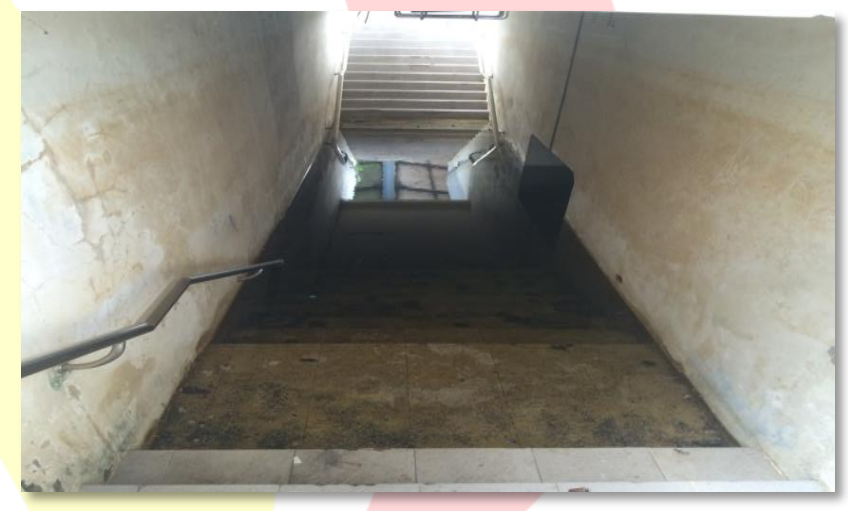

Gambar 7 terowongan penghubung halte

Kondisi ini membuat keselamatan untuk menyebrangi jalan rel menjadi sangat berbahaya karena langsung melewati jalan rel dan tidak disediakan tangga untuk turun dari halte. Selain kondisi terowongan penghubung, beberapa fasilitas lain juga sangat kurang, seperti ketersediaan bangku hanya ada pada loket pembelian tiket. Sedangkan beberapa fasilitas lain sudah beralih fungsi dan digunakan oleh masyarakat sekitar untuk menunjang aktivitas mereka sehari - hari. 


\section{Halte margorejo}

Letak dari halte Margorejo dikeluarahan Margorejo, kecamatan Wonocolo Kota Surabaya. Halte ini terletak pada ketinggan $+5 \mathrm{~m}$.

Ke arah selatan berjarak 1,5 km terdapat Stasiun Wonokromo. Posisi dari halte ini diapit 2 jalan raya besar yaitu jalan raya Frontage Ahmad Yani dan jalan raya Ahmad Yani. Halte ini juga berada pada pusat perbelanjaan besar di Surabaya yaitu Maspion Square sehingga mayoritas penumpang yang naik dan turun dihalte ini adalah orang yang ingin berbelanja atau berwisata. Pada halte ini terdapat 1 jalur rel kereta dan bangunan halte. Halte ini hanya kereta commuter Surabaya Porong yang berhenti disini.

$>$ Aksesbilitas :

Halte Margorejo memiliki aksesbilitas yang mudah untuk dijangkau, karena posisinya yang berada dekat dari jalan mayor, yaitu Jalan Raya Ahmad Yani dan Jalan Raya Frontage Ahmad Yani,Halte ini terletak di lingkungan pusar perbelanjaan. Namun sangat disayangkan tidak tersedia angkutan umum pada lingkungan Halte Margorejo. Kondisi internmoda yang kurang pada Halte Margorejo mempersulit para pengguna komuter yang ingin menuju lokasi lain, karena harus menunggu lyn melintasi lingkungan halte. Ketersediaan pedestrian sebidang dan pedestrian crossing masih kurang yang dapat membahayakan pejalan kaki terhadaap lalulintas sekitar.

Kondisi Halte Margorejo yang langsung bersinggungan dengan lalulintas kendaraan bermotor diharapkan dapat meningkatkan keselamatan dan keamanan para pengguna moda, salah satunya adalah dengan memperlebar kereb atau meninggikan pagar pembatas.

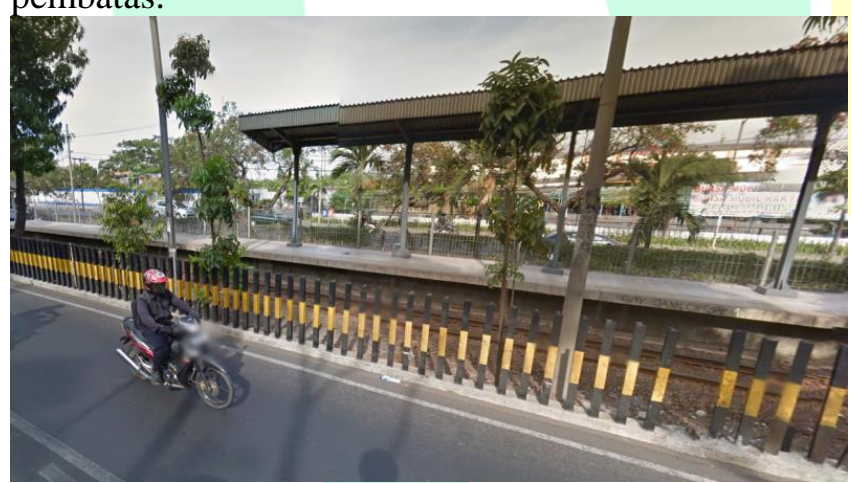

Gambar 8 halte margorejo bersinggungan langsung dengan lalu lintas

\section{Fasilitas pada Halte Margorejo}

Dimensi dari halte ini $3 \mathrm{~m} \times 100 \mathrm{~m}$, fasilitas yang ada pada halte ini masih terawat dengan baik. Sebagai contoh adalah tempat parkir yang tidak dimanfaatkan, sangat disayangkan untuk beberapa pagar pembatas sudah rusak dan terlepas serta ketersediaan bangku sebagai tempat menunggu Komuter Supor hanya tersedia di loket pembelian tiket.

\section{Halte sawotratap}

Letak dari halte sawotratap berada di desa Sawotratap, kecamatan Gedangan, kabupaten Sidoarjo. Letak posisinya berada pada utara stasiun waru sekitar kurang lebih $1.5 \mathrm{~km}$. halte ini juga terletak didekat perlintasan jalan menuju atau dari Bandara Juanda Surabaya sehingga bisa direncanakan konektifitas dari halte ini dengan angkutan moda dari atau ke bandara Juanda. Halte Sawotratap dulunya bernama Halte Makro.

$>$ Aksesbilitas :

Halte Sawotratap memiliki aksesbilitas yang mudah untuk dijangkau, karena posisinya yang berada dekat dari jalan mayor, yaitu Jalan Raya Waru. Sebagai satusatunya halte yang disinggahi oleh bus untuk angkutan ke Bandara Juanda fasilitas seperti tempat perhentian bus masih sangat kurang dari kata layak, karena hanya memanfaatkan bahu jalan.

Apabila kondisi bahu dapat dimaksimalkan dengan dibuatnya pemberhentian bus, kondisi ini dapat dimanfaat sebagai perbaikan intermoda antara KA angkutan umum.

$>$ Fasilitas pada Halte Sawotratap

Halte ini berdimensi $3 \mathrm{~m} \times 100 \mathrm{~m}$, fasilitas Halte Margorejo masih cukup terawat namun kurang dimaksimalkan. Sebagai contoh adalah tempat parkir yang sudah syarat kapasitas, dapat dilihat pada gambar diatas. Halte Sawotratap sebagai lokasi intermoda adalah halte yang syarat dengan penumpang, namun nyatanya fasilitas seperti pedestrian yang masih kurang baik pedestrian sebidang atau pedestrian crossing. Fasilitas penumpag KA Komuter Supor juga masih seperti tempat duduk yang terbatas.

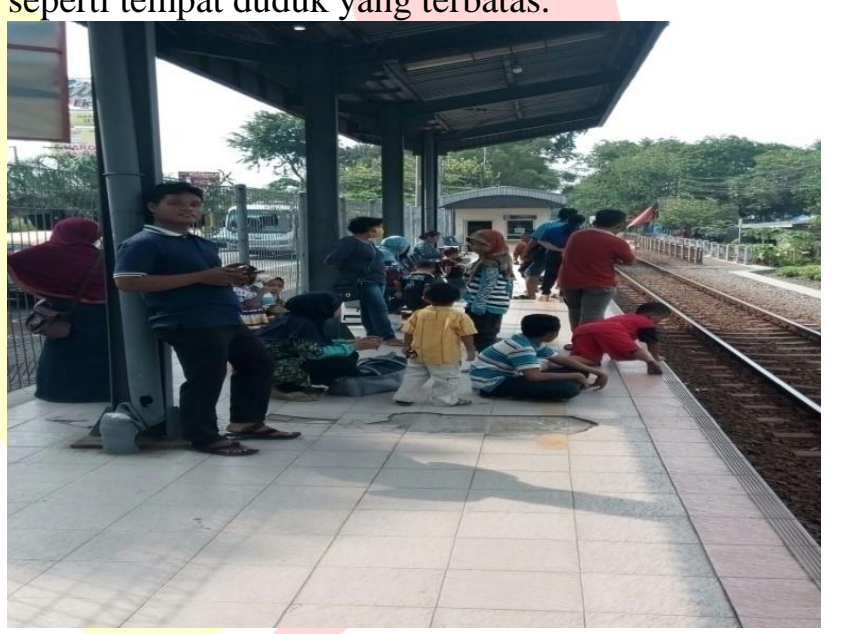

Gambar 9 tempat duduk yang ada di halte Sawotratap

Diharapkan terdapat evaluasi untuk ketersediaan pedestrian pada sisi dalam karena jarak yang terlalu dekat dengan KA, dapat membahayakan penduduk sekitar, fasilitas dapat ditingaktkan dengan pagar pembatas yang ditinggikan atau dibuat lebih menjorok kedalam. 


\section{Halte Banjarkemantren}

Letak halte Banjarkemantren berada pada perbatasan desa Banjarkematren dan desa buduran, kecamatan buduran kabupaten Sidoarjo. Halte ini juga berada pada kompleks kawasan industri kabupaten Sidoarjo seperti perusahaan maspion dan lain lain. Pada halte ini hanya memiliki satu jalur rel kereta api, kereta yang berhenti hanya kereta commuter Surabaya Porong.

$>$ Aksesbilitas :

Halte Banjarkemantren memiliki aksesbilitas yang mudah untuk dijangkau, karena posisinya yang berada dekat dari jalan mayor, yaitu Jalan Raya Surabaya Malang.

Namun untuk menjangkau halte tidak dapat langsung dari Jalan Raya Surabaya - Malang, halte harus melewati persimpangan Jalan Lingkar Timur terlebih dahulu.

\section{> Fasilitas pada Halte Banjarkemantren}

Dimensi dari halte ini $3 \mathrm{~m} \mathrm{x} 100 \mathrm{~m}$, fasilitas yang ada pada halte ini masih terawat dengan baik. Dapat dilihat dari kebersihan dan ketersediaan fasilitas, seperti pagar pembatas, tempat sampah, papan jadwal kedatangan dan tempat parkir. Kekurangan pada halte ini adalah ketersediaan tempat duduk yang masih sangat terbatas dan pada bahu jalan halte dimanfaatkan oleh pedagang kaki lima sebagai tempat berjualan.

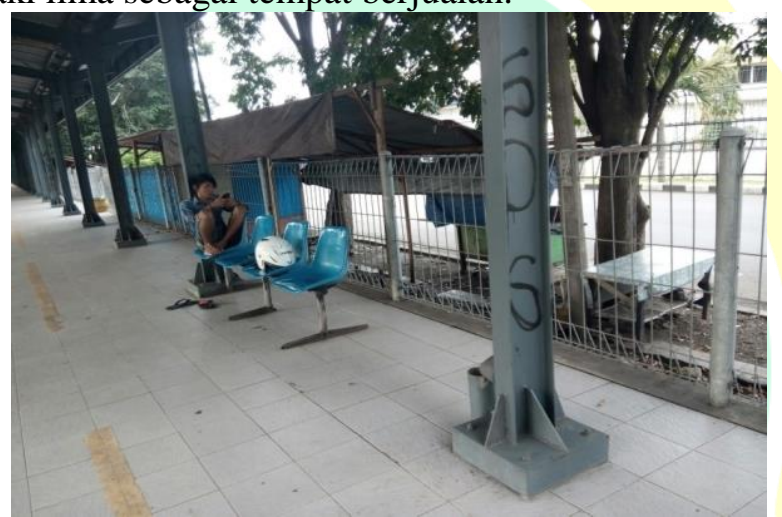

Gambar 10 tempat duduk yang ada dihalte banjar kemantren

\section{Halte buduran}

Halte buduran terletak di Desa Buduran, Kecamatan Buduran, Kabupaten Sidoarjo. Halte ini dulunya merupakan stasiun kelas III yang berubah fungsi menjadi halte. Kawasan halte ini terdapat museum Mpu Tantular yang berjarak sekitar $750 \mathrm{~m}$ diselatan halte. Jalur kereta pada halte ini hanya ada 1 jalur rel kereta api dan kereta api yang berhenti hanya kereta commuter Surabaya Porong.

$>$ Aksesbilitas :

Halte Buduran memiliki aksesbilitas yang cukup mudah untuk dijangkau, karena posisinya yang berada tidak jauh dari jalan mayor, yaitu Jalan Raya Surabaya - Malang. Namun untuk menuju halte harus melewati persimpangan Jalan Raya Surabaya - Malang dan Jalan
Raya Buduran. Posisi Halte masuk kedalam daerah pemukiman sehingga ketersediaan angkutan umum sangat minim harus menuju keluar lokasi halte untuk menunggu lyn yang lewat.

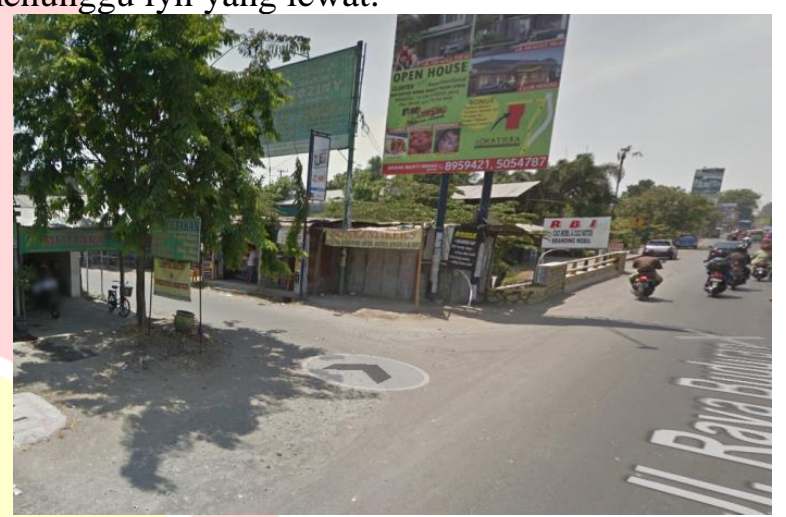

Gambar 11 aksesibilitas menuju lokasi halte buduran

\section{Fasilitas pada Halte Buduran}

Halte ini berdimensi $3 \mathrm{~m}$ x $100 \mathrm{~m}$, lokasi halte cukup dekat dengan pemukiman warga. Fasilitas-fasilitas yang tersedia pada halte ini adalah loket pembelian tiket, tempat parkir, toilet, serta ruang tunggu. Kondisi halte ini sudah kurang terawat seperti lantai yang terkelupas dan rusak hal ini dapat menyebabkan kenyamanan penumpang terganggu. Seperti pada masalah halte sebelumnya,halte ini juga hanya memeiliki sedikit jumlah tempat duduk bagi calon penumpang.

\section{Halte Pagerwojo}

Halte pagerwojo beradadi desa pagerwojo kecamatan buduran kabupaten Sidoarjo. Posisi halte terletak pada jalan Mayjen Sungkono Sidoarjo ini memiliki satu jalur rel kereta api. Kereta api yang berhenti hanya kereta commuter Surabaya Porong.

\section{$>$ Aksesbilitas:}

Halte Buduran memiliki aksesbilitas yang mudah untuk dijangkau oleh calon penumpang Komuter Supor karena posisinya dekat jalan mayor tepatnya adalah di Jalan Mayjen Sungkono, dapat dilihat seperti pada gambar dibawah ini.

Namun pada lokasi halte pagerwojo interrmoda dari KA - angkutan umum tidak terlalu diperhatikan, jadi para penumpang harus menunggu terlebih dahulu lyn yang melewati lokasi halte.

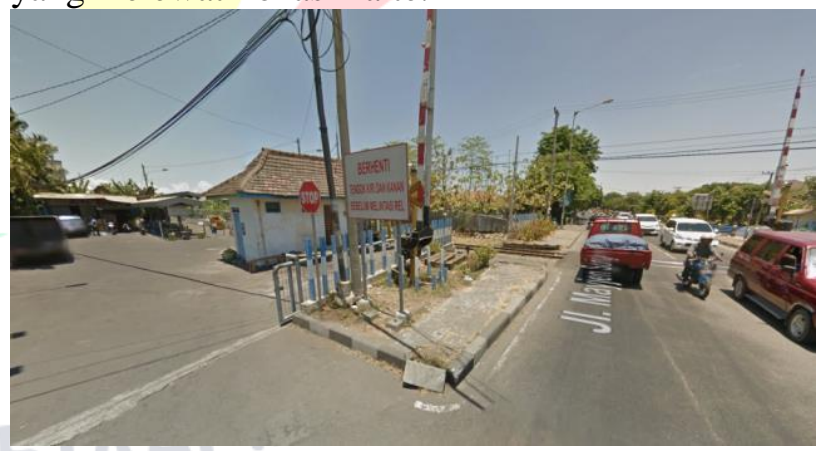

Gambar 12 lokasi menuju halte pagerwojo 
Fasilitas pada Halte Pagerwojo

Halte ini berdimensi $3 \mathrm{~m}$ x $100 \mathrm{~m}$, fasilitas - fasilitas yang tersedia adalah toilet, tempat parkir, loket pembelian tiket, serta ruang tunggu. Sangat disayangkan pada halte ini kondisi lantai halte sudah terkelupas dan rusak, ini dapat menyebakan kenyamanan dan keamanan terganggu. Seperti pada masalah halte sebelumnya,halte ini juga hanya memeiliki sedikit jumlah tempat duduk bagi calon penumpang.

\section{Analisa Tingkat Pelayanan Pejalan Kaki (Level Of Servis)}

Evaluasi tingkat pelayanan pada halte dan peron sebagai fasilitas pedestrian diselesaikan menggunakan formula 3 dengan asumsi waktu pengamatan selama 15 menit. Hasil analisa kereta komuter Surabaya Porong untuk tingkat pelayanan pada halte dan peron yang dilalui oleh kereta api, adalah sebagai berikut :

1. Data geometrik dapat dilihat pada tabel dibawah ini

Tabel 2 Data Geometrik Lebar Jalan Efektif Halte dan Peron

\begin{tabular}{|c|l|c|c|}
\hline \multirow{2}{*}{ No } & \multirow{2}{*}{ Stasiun / Shelter } & \multicolumn{2}{c|}{$\begin{array}{c}\text { Lebar Jalan } \\
\text { Efektif }\end{array}$} \\
\cline { 3 - 4 } & & $\begin{array}{c}\text { We } \\
\text { (feet) }\end{array}$ & $\begin{array}{c}\text { We } \\
\text { (meter) }\end{array}$ \\
\hline 1 & Stasiun Surabaya Kota & 1,46304 & 4,8 \\
\hline 2 & $\begin{array}{l}\text { Stasiun Surabaya } \\
\text { Gubeng }\end{array}$ & 1,46304 & 4,8 \\
\hline 3 & Halte Ngagel & 0,64008 & 2,1 \\
\hline 4 & Stasiun Wonokromo & 0,82296 & 2,7 \\
\hline 5 & Halte Margorejo & 0,64008 & 2,1 \\
\hline 6 & Halte Jemursari & 0,64008 & 2,1 \\
\hline 7 & Halte Kerto Menanggal & 0,64008 & 2,1 \\
\hline 8 & Stasiun Waru & 0,82296 & 2,7 \\
\hline 9 & Halte Sawo Tratap & 0,64008 & 2,1 \\
\hline 10 & Stasiun Gedangan & 0,97536 & 3,2 \\
\hline 11 & Halte Banjar Kemantren & 0,64008 & 2,1 \\
\hline 12 & Halte Buduran & 0,64008 & 2,1 \\
\hline 13 & Halte Pagerwojo & 0,64008 & 2,1 \\
\hline 14 & Stasiun Sidoarjo & 0,82296 & 2,7 \\
\hline 15 & Stasiun Tanggulangin & 0,64008 & 2,1 \\
\hline 16 & Stasiun Porong & 0,82296 & 2,7 \\
\hline & & & \\
\hline
\end{tabular}

a. Data jumlah penumpang yang berada pada halte dan peron, jurusan Surabaya - Porong adalah sebagai berikut :
Tabel 3 Data Jumlah Penumpang Surabaya - Porong

\begin{tabular}{|c|l|c|c|}
\hline \multirow{2}{*}{ No. } & \multirow{2}{*}{ Stasiun / Shelter } & \multicolumn{2}{|c|}{$\sum$ Penumpang } \\
\cline { 3 - 4 } & & & \multicolumn{2}{|c|}{} \\
\cline { 3 - 4 } & & Naik & Turun \\
\hline 1 & Stasiun Surabaya Kota & 23 & 0 \\
\hline 2 & Stasiun Surabaya Gubeng & 34 & 0 \\
\hline 3 & Halte Ngagel & 0 & 0 \\
\hline 4 & Stasiun Wonokromo & 19 & 0 \\
\hline 5 & Halte Margorejo & 4 & 0 \\
\hline 6 & Halte Jemursari & 3 & 2 \\
\hline 7 & Halte Kerto Menanggal & 0 & 0 \\
\hline 8 & Stasiun Waru & 0 & 0 \\
\hline 9 & Halte Sawo Tratap & 3 & 11 \\
\hline 10 & Stasiun Gedangan & 0 & 6 \\
\hline 11 & Halte Banjar Kemantren & 0 & 1 \\
\hline 12 & Halte Buduran & 1 & 3 \\
\hline 13 & Halte Pagerwojo & 0 & 5 \\
\hline 14 & Stasiun Sidoarjo & 2 & 20 \\
\hline 15 & Stasiun Tanggulangin & 1 & 21 \\
\hline 16 & Stasiun Porong & 0 & 21 \\
\hline & EPenumpang & & 90 \\
\cline { 2 - 4 } & & &
\end{tabular}

b. Data jumlah penumpang yang berada pada halte dan peron, jurusan Porong - Surabaya adalah sebagai berikut :

Tabel 4 Data Jumlah Penumpang Porong Surabaya

\begin{tabular}{|c|l|c|c|}
\hline \multirow{2}{*}{ No } & \multirow{2}{*}{ Stasiun / Shelter } & \multicolumn{2}{c|}{$\sum$ Penumpang } \\
\cline { 3 - 4 } & & & \multicolumn{2}{c|}{} \\
\cline { 3 - 4 } & & Naik & Turun \\
\hline 1 & Stasiun Porong & 6 & 0 \\
\hline 2 & Stasiun Tanggulangin & 9 & 0 \\
\hline 3 & Stasiun Sidoarjo & 8 & 0 \\
\hline 4 & Halte Pagerwojo & 13 & 0 \\
\hline 5 & Halte Buduran & 3 & 0 \\
\hline 6 & Halte Banjar Kemantren & 2 & 0 \\
\hline 7 & Stasiun Gedangan & 13 & 1 \\
\hline 8 & Halte Sawo Tratap & 0 & 4 \\
\hline 9 & Stasiun Waru & 4 & 5 \\
\hline 10 & Halte Kerto Menanggal & 2 & 1 \\
\hline 11 & Halte Jemursari & 0 & 6 \\
\hline 12 & Halte Margorejo & 0 & 5 \\
\hline 13 & Stasiun Wonokromo & 0 & 5 \\
\hline 14 & Halte Ngagel & 0 & 0 \\
\hline 15 & Stasiun Surabaya Gubeng & 0 & 25 \\
\hline 16 & Stasiun Surabaya Kota & 0 & 8 \\
\hline & EPenumpang & & 60 \\
\cline { 2 - 4 } & & & \\
\cline { 2 - 4 }
\end{tabular}


3. Hasil analisa level of service (LOS) berdasarkan laju arus pejalan kaki dalam orang/menit/feet untuk waktu pengamatan pukul 13.15 WIB - 14.34 WIB pada hari kamis 22 Oktober 2017 rute Surabaya - Porong adalah sebagai berikut

Tabel 5 Hasil Analisa LOS Halte dan Peron

\begin{tabular}{|c|c|c|c|c|}
\hline \multirow{3}{*}{ No. } & \multirow{3}{*}{ Stasiun / Shelter } & Arus penumpang & Arus Satuan Pleton & \multirow{3}{*}{ LOS } \\
\hline & & Periode $=$ Asumsi $15 \mathrm{mnt}$ & Periode $=$ Asumsi $15 \mathrm{mnt}$ & \\
\hline & & orang/menit/ft & orang/menit/ft & \\
\hline 1 & Stasiun Surabaya Kota & 1.048046078 & 5.048046078 & A - B \\
\hline 2 & $\begin{array}{l}\text { Stasiun Surabaya } \\
\text { Gubeng }\end{array}$ & 1.549285506 & 5.549285506 & A - B \\
\hline 3 & Halte Ngagel & 0 & 4 & $\mathrm{~A}$ \\
\hline 4 & Stasiun Wonokromo & 1.539159457 & 5.539159457 & A - B \\
\hline 5 & Halte Margorejo & 0.41661459 & 4.41661459 & $\mathrm{~A}$ \\
\hline 6 & Halte Jemursari & 0.520768237 & 4.520768237 & $\mathrm{~A}$ \\
\hline 7 & Halte Kerto Menanggal & 0 & 4 & A \\
\hline 8 & Stasiun Waru & 0 & 4 & $\mathrm{~A}$ \\
\hline 9 & Halte Sawo Tratap & 1.458151064 & 5.458151064 & A-B \\
\hline 10 & Stasiun Gedangan & 0.410104987 & 4.410104987 & $\mathrm{~A}$ \\
\hline 11 & $\begin{array}{l}\text { Halte Banjar } \\
\text { Kemantren } \\
\end{array}$ & 0.104153647 & 4.104153647 & $\mathrm{~A}$ \\
\hline 12 & Halte Buduran & 0.41661459 & 4.41661459 & $\mathrm{~A}$ \\
\hline 13 & Halte Pagerwojo & 0.520768237 & 4.520768237 & A \\
\hline 14 & Stasiun Sidoarjo & 1.782184634 & 5.782184634 & A - B \\
\hline 15 & Stasiun Tanggulangin & 2.291380244 & 6.291380244 & $\mathrm{~B}$ \\
\hline 16 & Stasiun Porong & 1.701176242 & 5.701176242 & A - B \\
\hline
\end{tabular}

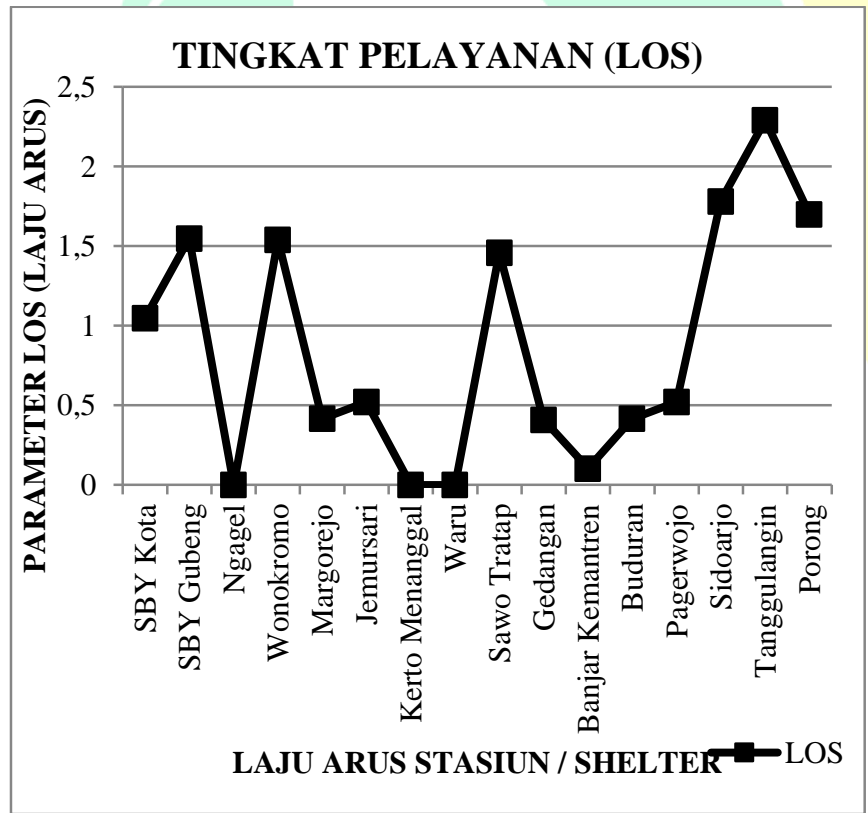

Gambar 13 Grafik LOS Dalam Laju Arus

Berdasarkan hasil analisa dengan laju arus pejalan kaki dalam orang/menit/feet pada waktu penelitian menunjukan bahwa LOS untuk halte dan peron masih sangat baik berkategori A - B. Kecepatan berjalan bebas dan mulai menyadari kehadiran pejalan kaki.

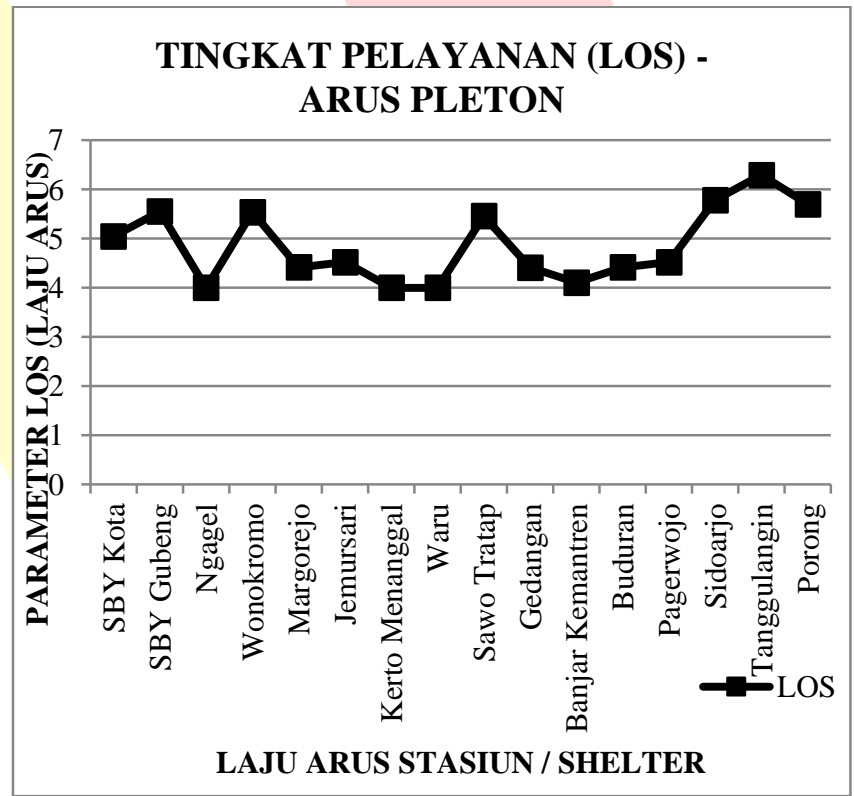

Gambar 14 Grafik LOS Dalam Laju Arus Pleton

4. Hasil analisa level of service (LOS) berdasarkan laju arus pejalan kaki dalam orang/menit/feet untuk waktu pengamatan pukul 15.50 WIB - 17.20 WIB pada hari senin 23 Oktober 2017 rute Porong - Surabaya adalah sebagai berikut : 


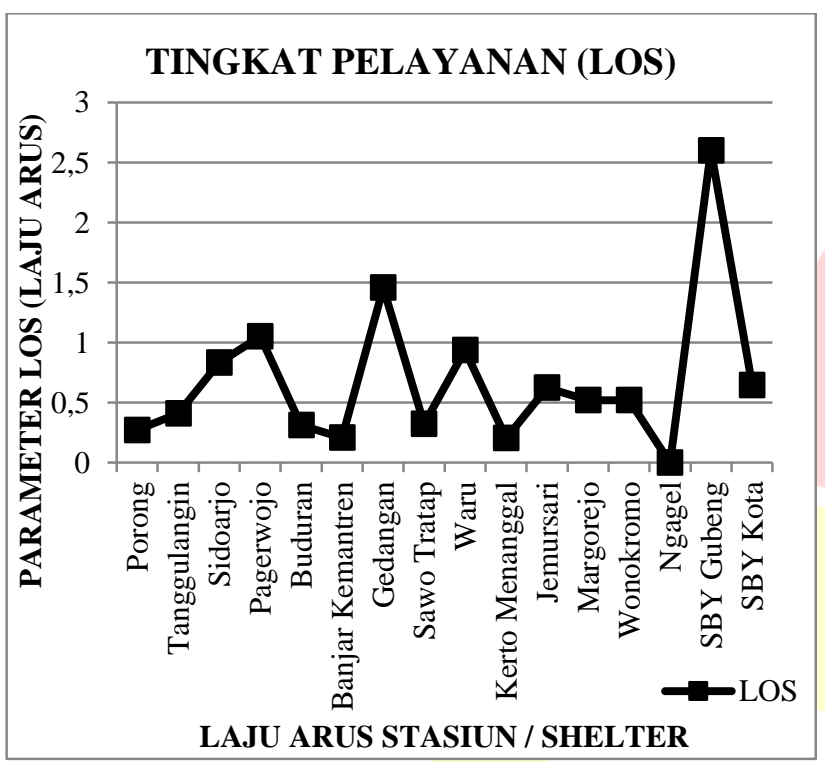

Gambar 15 Grafik LOS Dalam Laju Arus

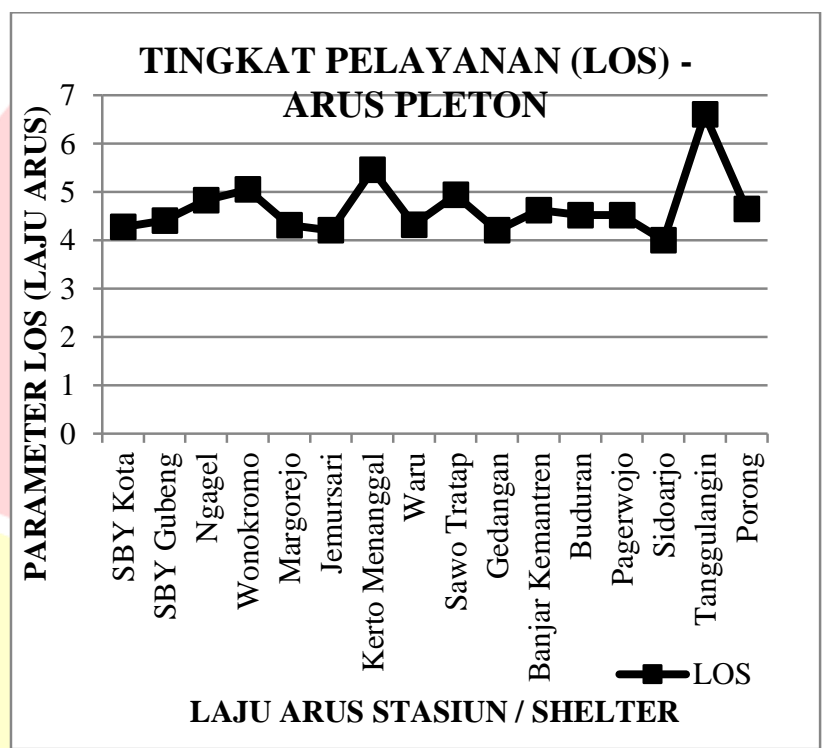

Gambar 16 Grafik LOS Dalam Laju Arus Pleton

Tabel 6 Hasil Analisa LOS Halte dan Peron

\begin{tabular}{|c|c|c|c|c|}
\hline \multirow{3}{*}{ No. } & \multirow{3}{*}{ Stasiun / Shelter } & Arus penumpang & Arus Satuan Pleton & \multirow{3}{*}{ LOS } \\
\hline & & Periode $=$ Asumsi $15 \mathrm{mnt}$ & Periode $=$ Asumsi $15 \mathrm{mnt}$ & \\
\hline & & orang/menit/ft & orang/menit/ft & \\
\hline 1 & Stasiun Porong & 0.273403325 & 4.273403325 & $\mathrm{~A}$ \\
\hline 2 & Stasiun Tanggulangin & 0.410104987 & 4.410104987 & $\mathrm{~A}$ \\
\hline 3 & Stasiun Sidoarjo & 0.83322918 & 4.83322918 & A \\
\hline 4 & Halte Pagerwojo & 1.053109102 & 5.053109102 & $A-B$ \\
\hline 5 & Halte Buduran & 0.312460942 & 4.312460942 & $\mathrm{~A}$ \\
\hline 6 & Halte Banjar Kemantren & 0.208307295 & 4.208307295 & $\mathrm{~A}$ \\
\hline 7 & Stasiun Gedangan & 1.458151064 & 5.458151064 & $A-B$ \\
\hline 8 & Halte Sawo Tratap & 0.32403357 & 4.32403357 & A \\
\hline 9 & Stasiun Waru & 0.937382827 & 4.937382827 & $\mathrm{~A}$ \\
\hline 10 & Halte Kerto Menanggal & 0.205052493 & 4.205052493 & $\mathrm{~A}$ \\
\hline 11 & Halte Jemursari & 0.624921885 & 4.624921885 & $\mathrm{~A}$ \\
\hline 12 & Halte Margorejo & 0.520768237 & 4.520768237 & A \\
\hline 13 & Stasiun Wonokromo & 0.520768237 & 4.520768237 & $\mathrm{~A}$ \\
\hline 14 & Halte Ngagel & 0 & 4 & A \\
\hline 15 & Stasiun Surabaya Gubeng & 2.603841187 & 6.603841187 & $\mathrm{~B}$ \\
\hline 16 & Stasiun Surabaya Kota & 0.64806714 & 4.64806714 & A \\
\hline
\end{tabular}

Berdasarkan hasil analisa dengan laju arus pejalan kaki dalam orang/menit/feet pada waktu penelitian menunjukan bahwa LOS untuk halte dan peron masih sangat baik karena berkategori A - B. Kecepatan berjalan bebas dan mulai menyadari kehadiran pejalan kaki yang lain.

\section{KESIMPULAN}

Berdasarkan hasil analisis tentang fasilitas pejalan kaki dan aksesibilitas halte dan stasiun kereta commuter Surabaya Porong dapat disimpulkan secara-umum fasilitas dan aksesibilitas dari halte dan stasiun masih sangat baik. Dari segi survey kepada responden didapatkan hasil bahwa pengguna kereta commuter saat ini merupakan masyarakat didaerah sekitar yang bertempat tinggal didaerah sekitar halte dan stasiun. Dari hasil survey juga tentang aksesbilitas didapatkan banyak dari responden sebelum dan sesudah naik kereta commuter menggunakan sepeda motor dan jalan kaki. Sehingga perlu di perhatikan tempat parkir untuk memarkirkan sepeda motor di lokasi halte stasiun dan koneksi dengan moda lain setelah menggunakan kereta commuter. 
Observasi lapangan yang dilakukan pada setiap halte didapatkan kondisi fasilitas didapatkan berupa toilet, tempat parkir, loket pembelian tiket, serta ruang tunggu dengan kondisi yang cukup baik meskipun ada beberapa yang kurang terawat. Tingkat pelayanan laju arus pejalan kaki dalam orang/menit/feet pada waktu survey menunjukan hasil nilai arus satuan pleton rata rata diatas 4 orang/menit/ft sehingga kategori LOS masih sangat baik dengan kategori A-B. kecepatan arus berjalan dan kemungkinan terjadinya konflik di aksesibilitas sangat kecil.

Dari segi aksesibilitas lokasi lokasi halte stasiun kereta commuter Surabaya Porong mudah untuk dijangkau oleh calon penumpang karena letaknya yang berdekatan dengan jalan raya, namun untuk koneksi dengan angkutan umum sebagian halte stasiun masih belum terkoneksi dengan baik sehingga kedepan perlu direncanakan koneksi dengan moda lanjutan atau moda sebelum menggunakan kereta.

\section{UCAPAN TERIMA KASIH}

Terima kasih kepada tim survey yang telah membantu penulis dalam melakukan observasi lapangan. Terima kasih kepada pihak responden yang telah bersedia untuk diwaancarai dalam kegiatan penelitian ini. Tak lupa kepada pihak stake holder PT. KAI Daop 8 Surabaya yang telah memberikan izin melakukan penelitian di halte dan stasiun kereta commuter Surabaya Porong

\section{REFERENSI}

Anggriani, N. (2009). Pedestrian Ways Dalam Perancangan Kota. Surabaya: Yayasan Humaniora.

Badan Pusat Statistik Kota Surabaya. 2016. Surabaya dalam Angka 2016. Surabaya: Badan Pusat Statistik Kota Surabaya

Harsono Syafiz, 2016, Persepsi Pejalan Kaki Terhadap Kenyamanan Jalur Pejalan Kaki Dipusat Kota Medan, Thesis, Fakultas Teknik Universitas Sumatera Utara, Medan.

Kementrian Pekerjaan Umum. 2014. Peraturan Menteri Pekerjaan Umum Nomor: 03/PRT/M/2014 tentang Pedoman Perencanaan, Penyediaan dan Pemanfaatan Prasarana dan Sarana Jaringan Pejalan Kaki di Kawasan Perkotaan. Jakarta.

Keputusan Menteri Perhubungan No. KM 65 Tahun 1993. (1993)., Fasilitas Pendukung Kegiatan Lalu Lintas dan Angkutan Jalan, (1993). Jakarta

Khisty, C.Jotin, Lall, B.Kent, 2003. Transportation Engineering. Third Edition, Pearson Education Inc, Upper Saddle River, New Jersey, USA, pp. 557-1576
Ofyar Z, Tamin (2000). Perencanaan dan Pemodelan Transportasi, ITB, Bandung

Soimun, Ahmad (2018). "Analisis Probabilitas Perpindahan Moda Pengguna Kendaraan Pribadi (Sepeda Motor dan Mobil) ke Kereta Api Commuter Surabaya Sidoarjo". Tesis Magister. Departemen Teknik Sipil. Institut Teknologi Sepuluh Nopember (ITS). Surabaya.

Sudiarta I Nyoman, 2017, Kajian Kondisi Pedestrian Ways Jalur Pejalan Kaki) di Jalan Waturenggong Kota Denpasar, Program Studi Arsitektur Fakultas Teknik Universitas Udayana, Denpasar.

Transportation Research Board. Highway Capacity Manual 2000. National Research Council, Washington. D.C., 2000. 